\title{
The Dynamics of Tsetse Flies Around the Mbam and Djerem National Park
}

\author{
Eteme Enama S. ${ }^{1,}$, , Njan Nloga A. M. ${ }^{2}$, Abah S. ${ }^{2}$, Ngo Bum E. \\ ${ }^{1}$ Faculty of Science, Department of Biological Sciences, University of Yaounde I, Yaounde, Cameroon \\ ${ }^{2}$ Faculty of Science, University of Ngaoundere, Ngaoundere, Cameroon
}

\section{Email address:}

sergeeteme@gmail.com (Eteme E. S.)

*Corresponding author

\section{To cite this article:}

Eteme Enama S., Njan Nloga A. M., Abah S., Ngo Bum E. Kumaresh. The Dynamics of Tsetse Flies Around the Mbam and Djerem National Park. Journal of Diseases and Medicinal Plants. Vol. 3, No. 3, 2017, pp. 42-48. doi: 10.11648/j.jdmp.20170303.11

Received: March 4, 2017; Accepted: March 22, 2017; Published: May 6, 2017

\begin{abstract}
A capture of tsetse flies was done between November 2014 and July 2016 in three localities around the Mbam and Djerem National Park. The biconic traps were used for the captures in Yoko, Mbakaou and Betare-Oya during 5 days. These traps permitted to capture 709 tsetse flies belonging to four species: Glossina fuscipes fuscipes (54.16\%), Glossina fusca congolensis (29.34\%), Glossina palpalis spp (7.19\%) and Glossina calliginea (9.31\%). The season did not influence the abundance of tsetse flies. In general, no significant influence was observed between the localities. Specifically, the Glossina palpalis spp species presented a significant difference in its distribution between the localities of Betare-Oya and Yoko $(\mathrm{P}=0.048)$. The Glossina calliginea species was also differently distributed between the traps close to a path in T4 enlightened area and the traps close to a path to $\mathrm{T} 3$ shade $(\mathrm{P}=0.042)$, presenting a direct link between the number of tsetse flies and the presence of cattle.
\end{abstract}

Keywords: Glossina Spp, Biconic Traps, Mbam and Djerem National Park

\section{Introduction}

Trypanosomose is a disease causes by blood protozoans called Trypanosoma, always present on vertebrates that constitute their milieu of life. All the trypanosomas (except the Trypanosoma equiperdum) have adixenous cycle which the intermediary host is abloodsuckinginsect. This insect can be a simple mechanic vector, in which trypanosomas survive. This role is insured bytabanidae orstomoxinae. The real biological vectors of trypanosomas which permit the multiplication of the parasite are tsetse flies (the type of Glossina) only present in Africa (Chartier and Co., 2000).

African animaltrypanosomiasisis one of the main obstacles to breeding in all sub-Saharan Africa. The most concerned domesticated animal by this disease remains cattle (FAO, 2002). Cameroon in 2012 counted 22271 signaled cases (Year statistics book of Cameroon, 2013). Africa has about 300 billioncattlewhich about one quarter is situated in the regions infested by tsetse flies (FAO, 2012). The annual productivity deficit represents 1 million tons of meat and 1.6 million tons of milk. In the absence of tsetse flies, the cattle livestock could increase by 33 million animals. The direct losses by mortality are aggravated by the indirect losses due to weight loss, morbidity and reproduction problems often difficult to quantify (abortion, sterility, increase of the interval between two calvings). According to the World Bank, the losses of incomes in agriculture vary between 800 and 1600 US million dollars in respect to the degree of the impact of trypanosomoses. In the other hand these losses underlie the decrease of the economic freedom for the Countries concerned and the reduction of food proteins available for human being.

The distribution of tsetse flies and the risk evaluation of the trypanosomose in Cameroon are not yet totally established. Despite the studies carried by many researchers (Asonganyi and Co., 1990; Morlais, 1998; Njiokou and Co., 2006; Simo and Co., 2006; Njitchouang and Co., 2010; Farikou and Co., 2010; Simo and Co., 2012), there is less knowledge on the effective of tsetse flies in many bleeding areas, which constitutesan obstacle for animal production. On other hand, in reason of its bioclimatic factors and of the 
diversity of its ecosystems, Cameroon has favorable zones for the development of tsetse flies. In addition, Cameroon has many historical sources of infection on sleeping sickness in certain regions which some have not been prospected for more than 40 years. While cases of TAA often signaledin proximity with parks give rise to a certain worry.

The geographic location of the Mbam and Djerem National Park (MDNP) in ecotone zone or of forest savanna transition, where coexist forest species, savanna species and ubiquitous species is recognized by scientists as being riche in endemic species and favorable to speciation (MINFOF, 2007). These particularities in the ecological and biological domain make the MDNP, the protected area, potentially housing tsetse flies. According to Mavoungou (2007), the parks overflow many pathogenic agents that can be transmitted by the insects' vectors; namely bloodsucking flies like Tsetse flies, Stomoxys and Tabanidae.
This work is carried in this area given the ecomomic importance of the MDNP, of its importance in the ecotouristicmap of Cameroon, considering the rush of farmers to the proximity of the park and the road infrastructures in course of realization.

\section{Material and Methods}

\section{Research Zone}

The MDNP covers four thousands two hundred kilometers square which half is made of tropical forest, plains, the other half of wooded savanna and Soudan-Guinean woody savanna with between the two a large ecotone belt (Maisels, 2004). This overlap of two zones of vegetation confers to the Mbam and Djeremnational park the biggest diversity of habitats of all the protected areas of Cameroon.

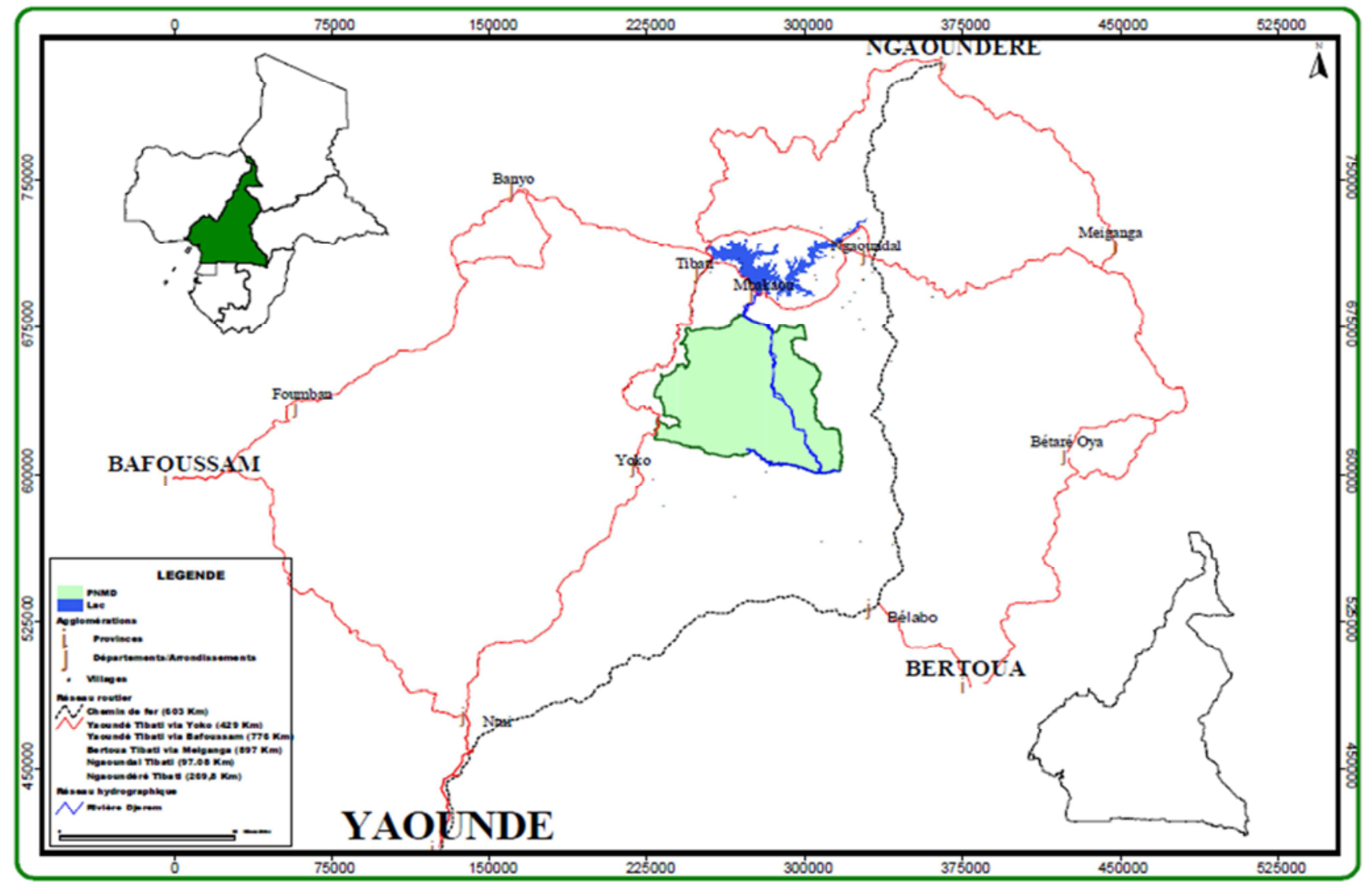

Figure 1. Location of the Mbam and Djerem National Park in Cameroon space (MINFOF, 2007).

The new national park possesses forestry galleries, transition forests and humid forests, different types of savannas, moving from woody savannas almost completed closed, passing through bushy savannas to opened grassland, seasonable flooded, through the principal rivers which one presents spectacular waterfalls.

All this natural wealth is diversely distributed between the three regions of the Center by the station of Yoko, of the East by the station of Betare-Oya and the Adamaoua by the station of Mbakaou.

The three (03) stations present two variable seasons in respect to the zones. Despite these similarities, there are also specificities. Indeed, in Betare-Oya such in Yoko the unimodal nature of the raining seasons is less marked than Bakaou. In Betare-Oya, from mid-May there is a decrease of the curve till mid-July and a slow increase from mid-May till mid-Juneuntil the maxima of September and October. In Yoko the inflexion is short (from mid-May to mid-June) then a slow increase from mid-June to the maxima of September and October.

Transhumance which is the moving of cattle to seek available food also falls under the dynamics of these vectors. 
It takes place differently, depending on the localities (Yoko: mid-November to December, Mbakaou: end March to May and Betare-Oya: mid-December to May).

\section{Methodology}

\subsection{Captureof Insects}

The trapping, originally employed as a technique of fighting, is used as method of sampling in the ecological research on tsetse flies since the appearance of the biconic trap of Challier-Laveissière (1973). It constitutes a more representative sampling technique of the populations than the capture with a net (Gouteux and Dagnogo, 1986). Based on the principle of visual attraction, it attracts tsetse flies thanks to it blue cobweb. After they are posited on black bands; then, by flying back moving to the light, they are imprisoned in a mosquito net tulle coneshaped where they will enter a capture trap.

During our investigations carried from November 2014 to July 2016, the tsetse flies were captured thanks to these biconic traps.

\subsection{Sampling of Tsetse Flies}

The captures were done during five consecutive days in order not to affect the dynamics of the populations studied and therefore have sufficient numbers of the population for a longitudinal study. The captures were done in day time to respect the activity period of tsetse flies. The traps were activated in the morning before 08am and removed in the evening after $5 \mathrm{pm}$. During the removal of traps, the capture nets were marked with the number mentioned on the trap and brought back to the laboratory for identification. In the laboratory, the tsetse flies have been separated from dipterans, then counted and identified under a binocular magnifying glass with the use of the identification keys published by Brunhesand Co. (1998).

\subsection{Disposition of Traps}

In each of the zones of the study, 05 traps distant one another for at least 500mweredistributed in the different biotopes found. We will gather them into five indications: the traps near a stalling park (T1), the traps near a river (T2), the traps near a shade path (T3), the traps near a path in a lightened zone (T4) and the traps near houses (T5).

\subsection{Data Analysis}

The abundance of tsetse flies species captured in the zone of the study was defined by the apparent density per trap and per day (ADT) calculated according to the following formula:

$$
A D T=\frac{\text { Number of captured tsetse flies }}{\text { Number of trapsxNumber of days of capture }}
$$

The relation $\mathrm{V} / \mathrm{A}(\mathrm{V}=$ variance and $\mathrm{A}=$ average) permitted us to establish the distribution of insects. The Margalefindex of diversity was calculated to evaluate the diversity of these insects in the areas prospected. This index was calculated using the formula: $\mathrm{D}=(\mathrm{S}-1) / \log \mathrm{N}$, where "S" is the number of species and " $\mathrm{N}$ " the total number of the individuals gathered (Legendre \& Legendre, 1998). So, when this index is above 1 , the milieu is rich in species fairly distributed.

\section{Results}

\subsection{Specific Composition of the Tsetse Flies Captured}

The different captures realized during this study permitted to note1726 Dipterans among which 1017 are mechanic vectors $(58.92 \%)$ and 709 tsetse flies $(41.08 \%)$. Among the mechanic vectors, we note 553 Tabanidae (277 Atylotusagrestis and 256 Tabanusbovinus), 386 Muscidae represented by Stomoxyscalcitrans and 98 Muscidae (Simuliumdamnosum) (Table 1).

Table 1. variations rate of different insects during the captures by biconic traps from the month of November 2014 to July 2016 in the localities of Yoko (Centre), Mbakaou (Adamaoua) and Betare-oya (East).

\begin{tabular}{lll}
\hline Species & Numbers & Proportions (\%) \\
\hline Glossines (G. fuscipes. fuscipes, G. fusca & 709 & 41.10 \\
congolensis, G. palpalis et G. calliginea) & & \\
Tabanus bovinus & 256 & 14.83 \\
Atylotus agrestis & 277 & 16.04 \\
Stomoxys calcirans. & 386 & 22.35 \\
Simulium damnosum & 98 & 5.68 \\
TOTALS & 1726 & 100 \\
\hline
\end{tabular}

The above chart shows that the mechanic vectors are significantly more important than biologic vectors. ( $Z=$ 7.49 ), with proportions of $59 \%$ against about $41 \%$. These proportions permit to maintain the transmission in the absence of biologic vectors.

On the 709 tsetse fliesobserved during our entomologic investigation, the different species were identified Glossinafuscipesfuscipes Glossinafuscacongolensis (29.34\%), Glossinapalpalisspp (7.19\%) and Glossinacalliginea (9.31\%) (Figure 2).

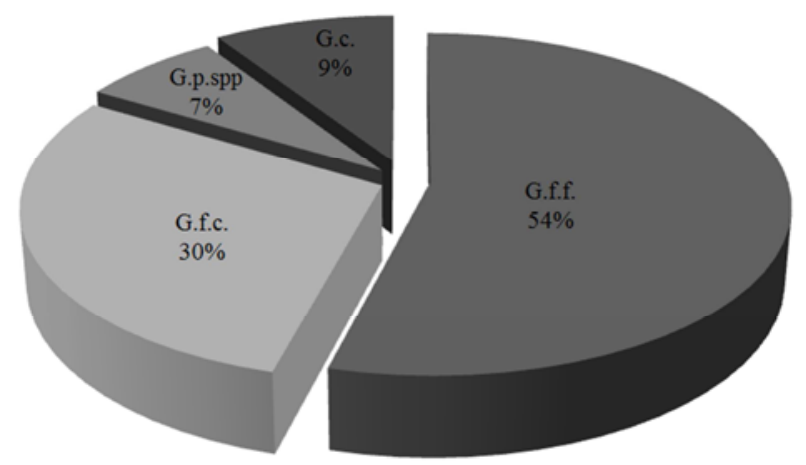

Figure 2. Specific compositions of captured tsetse flies during the entomologic investigation from November 2014 toJuly 2016 in Yoko (Centre), Mbakaou (Adamaoua) and Betare-oya (East).

G.f.f.: Glossinafuscipesfuscipes; G.f.c.: Glossinafuscacongolensis; G.p.spp: Glossinapalpalisspp; G.c.: Glossinacalliginea 
The four species of the tsetse flies were present in all the prospected localities (Figure 3). Only the Glossina palpalis spp species has presented a significant difference in its distribution between the localities of Betare-Oya and Yoko ( $p$ $=0.048$ ). This figure confirms the high rate of Glossina fuscipes fuscipes no matter the place of capture. The important presence of Glossina palpalis spp in a locality testifies its initial presence in this locality before the installation of the park.
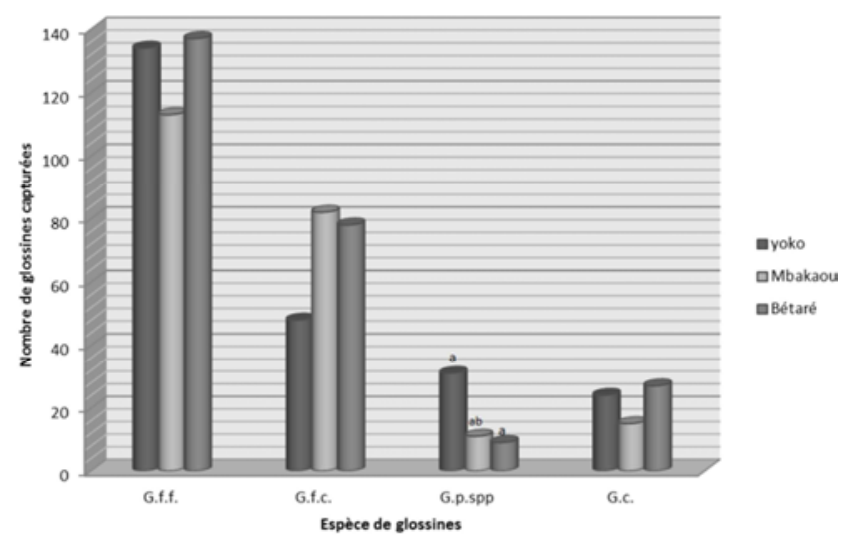

Figure 3. Composition of the different tsetse flies species captured during the entomologic investigation from November 2014 to July 2016 in Yoko (Centre), Mbakaou (Adamaoua) and Betare-oya (East).

G.f.f.: Glossina fuscipes fuscipes; G.f.c.: Glossina fusca congolensis; G.p.spp: Glossina palpali sspp; G.c.: Glossina calliginea

$\mathrm{a}, \mathrm{b}$ : the difference of the letter indicates the significant difference

\subsection{Distribution of Tsetse Flies}

The analysis of the samplings results obtained during this entomologic investigation shows that the ratio is lower to 1 for all the distributions. This leads to an homogeneous distribution in all the localities during all the seasons and before, during and after transhumance (Table 2). This value also confirms that the moving of cattle at the time of transhumance does not modify the data of the transmission due also to the moving of the vectors with the animals.

Table 2. Distribution of tsetse flies species captured during the entomologic investigation from November 2014 to July 2016 in Yoko (Centre), Mbakaou (Adamaoua) and Betare-oya (East).

\begin{tabular}{llllll}
\hline & Season & \multicolumn{4}{c}{ Transhumance } \\
\hline & $\begin{array}{l}\text { Raining } \\
\text { season }\end{array}$ & $\begin{array}{l}\text { Dry } \\
\text { season }\end{array}$ & Before & During & After \\
\hline Yoko & 0.111 & 0.053 & 0.014 & 0.040 & 0.076 \\
Mbakaou & 0.004 & 0.005 & 0.003 & 0.004 & 0.009 \\
Betare-Oya & 0.001 & 0.001 & 0.003 & 0.00007 & 0.003 \\
\hline
\end{tabular}

\subsection{Influence of the Season on the Capture in the Localities Prospected}

These Margalef (D) indexes of diversity were respectively of 1.26in Yoko-Meteing, of 1.28 in Mbakaou-Quarry andof1.25 in Betare-Oya. The four species were found in all the sites and during the two seasons (Table 3 ).

This chart shows that the densities of captured flies are globally weak. The density of flies was higher in dry season than in raining season. The weakest density was noted in Mbakaou $(\mathrm{ADT}=0.02 \mathrm{G} / \mathrm{P} / \mathrm{J})$ in the raining season near the stalling park. In Yoko, the highest density was noted in shade near the path $(\mathrm{ADT}=0.0864 \mathrm{G} / \mathrm{P} / \mathrm{J})$. This shows that flies follow the moving of cows to become more important near the paths.

In dry season also, the highest density was observed near the path in shade (T3) in Mbakaou-Quarry $(\mathrm{ADT}=0.24 \mathrm{G} / \mathrm{P} / \mathrm{J})$, followed by Yoko $(\mathrm{ADT}=0.22 \mathrm{G} / \mathrm{P} / \mathrm{J})$ (Table 3). This last one presented the weakest density of tsetse flies $(\mathrm{ADT}=0.0225 \mathrm{G} / \mathrm{P} / \mathrm{J})$ near houses (T5). In Mbakaou the densities are between 0.1 and $0.13 \mathrm{G} / \mathrm{P} / \mathrm{J}$.

Table 3. Abundance of captured tsetse flies in respect to the season during the entomologic investigation from November 2014 to July 2016 in Yoko (Centre), Mbakaou (Adamawa) and Betare-oya (East).

\begin{tabular}{lllllll}
\hline Season & Sites & T1 & T2 & T3 & T4 & T5 \\
\hline \multirow{4}{*}{ Raining } & Yoko & 0.0368 & 0.0432 & 0.0864 & 0.0272 & 0.0416 \\
& Mbakaou & 0.02 & 0.0333 & 0.0555 & 0.0411 & 0.0411 \\
& Betare-Oya & 0.0377 & 0.0433 & 0.0433 & 0.05 & 0.0377 \\
\multirow{4}{*}{ Dry } & Yoko & 0.16 & 0.11 & 0.22 & 0.06 & 0.0225 \\
& Mbakaou & 0.16 & 0.16 & 0.24 & 0.2 & 0.2 \\
& Betare-Oya & 0.12 & 0.13 & 0.1 & 0.13 & 0.12 \\
\hline
\end{tabular}

\subsection{Influence of the Transhumance on the Capture in the Localities Prospected}

The indexes of diversity undergone weak variations, therefore we noted a value of 1.21 before the transhumance, of1.34 during and 1.27 after.

The analysis of the results permits to say that before the departure of cattle, the weakest density is noted near a path in an enlighten zone $(A D T=0.0272 \mathrm{G} / \mathrm{P} / \mathrm{J})$. Independently of ecologic zones, the sites of Yoko and Mbakaou presented weak densities in respect to those of Betare-Oya (Table 4).

During the transhumance, the sites of Betare-Oya and Mbakaou have presented weak densities in respect to those of Yoko. This last one has presented the highest density near a path in shade $(\mathrm{ADT}=0.22 \mathrm{G} / \mathrm{P} / \mathrm{J})$. This difference could be due to the density of cattle present in the zones of study. Thus, we note theweakestnumber of cows in Yoko.

After the transhumance, the densities are variable in relation to the zones. Thus, we note $0.066 \mathrm{G} / \mathrm{P} / \mathrm{J}$ in Mbakaou and $0.32 \mathrm{G} / \mathrm{P} / \mathrm{J}$ in Yoko. The highest densities were found on the traps situated near the path in shade (P3): Yoko$\mathrm{ADT}=0.32 \mathrm{G} / \mathrm{P} / \mathrm{J} ; \quad$ Mbakaou-ADT $=0.16 \mathrm{G} / \mathrm{P} / \mathrm{J} ; \quad$ Betare-Oya$\mathrm{ADT}=0.19 \mathrm{G} / \mathrm{P} / \mathrm{J}$.

Table 4. Abundance of captured tsetse flies in respect to the transhumance during the entomologic investigation from November 2014 to July 2016 in Yoko (Centre), Mbakaou (Adamawa) and Betare-oya (East).

\begin{tabular}{lllllll}
\hline $\begin{array}{l}\text { Transhu } \\
\text { mance }\end{array}$ & Sites & T1 & T2 & T3 & T4 & T5 \\
\hline \multirow{3}{*}{ Before } & Yoko & 0.0368 & 0.0432 & 0.0896 & 0.0272 & 0.0416 \\
& Mbakaou & 0.0444 & 0.08 & 0.0755 & 0.0622 & 0.0577 \\
& Betare-Oya & 0.14 & 0.14 & 0.19 & 0.18 & 0.15 \\
During & Yoko & 0.11 & 0.11 & 0.22 & 0.06 & 0.09 \\
& Mbakaou & 0.03 & 0.05 & 0.07 & 0.06 & 0.06 \\
& Betare-Oya & 0.0425 & 0.045 & 0.04 & 0.0425 & 0.0425 \\
\hline
\end{tabular}




\begin{tabular}{lllllll}
\hline $\begin{array}{l}\text { Transhu } \\
\text { mance }\end{array}$ & Sites & T1 & T2 & T3 & T4 & T5 \\
\hline \multirow{3}{*}{ After } & Yoko & 0.08 & 0.2 & 0.32 & 0.24 & 0.12 \\
& Mbakaou & 0.0666 & 0.0933 & 0.16 & 0.1155 & 0.1288 \\
& Betare-Oya & 0.14 & 0.14 & 0.19 & 0.18 & 0.15 \\
\hline
\end{tabular}

\section{Discussion}

The results obtained in this study confirm the attractiveness of these traps in the capture of bloodsucking flies as had already signaled many authors, namely Amsler and Filledier (1994), Gilles and Co. (2005), Bitome and Co. (2015), Dibakou and Co. (2015), Mounioko and Co. (2015). Therefore, the results obtained in this study could be explained by the exclusive use of this type of trap. Indeed, despite the fact that the efficiency of this trap for the capture of bloodsucking flies is known (Jaenson and Co., 1991; Mihok and Co., 1995; Gilles, 2005; Gilles and Co., 2007; Mavoungou; 2007, Mavoungou and Co., 2012; Zinga and Co., 2013; Mbang and Co., 2015), the association of many types of trap and the addition of olfactory attractives like the octenol only or in association with phenols would permit to increase the height of the sampling (Djiteye, 1992; Djiteye; 1994; Mihok, 2002; Krčmar and Co., 2006; Krčmar 2007; Van Hennekeler and Co., 2008; Mihok and Mulye, 2010; Mihok and Lange, 2012).

This trap permitted us to capture four species which belong to two groups (sub-types), namely Austenina (Fusca) for Glossina fusca congolensis and Nemorhina (Palpalis) for Glossina fuscipes fuscipes, Glossina palpalis spp and Glossina calliginea. These species belong to the species inventoried in (Rageau and Adam, 1953). In other hand, these results have permitted to confirm the presence that Glossina palpalis spp and Glossina fuscipes fuscipes, are the main vectors of THA (Maillot, 1953). These species were found in all the three stations. The tsetse flies were abundant and diversified in the three localities. These results could be in relation with the ecologic requirements of each of the captured species in particular G. palpalis spp, G. fuscipes fuscipes, G. calliginea and G. fusca congolensis which seem to find favorable conditions to their development in these zones. This is explained by the fact that the abundance and the specific wealth of the entomofauna in a given place and defined by a certain abiotic and biotic factors (Desquesnes and Co., 2005). Studies done by many authors (Frezil and Carnevale, 1976; Zinga and Co., 2013; Zinga and Co., 2014) have shown that the conjunction of many factors such as a dense vegetation and the presence of nutrient hosts (animals and human being) could be at the origin of the forte density of tsetse flies in a given zone.

The Margale findex of diversity, that leads to a specific wealth in a biotope has almost been similar in the three localities: Betare $(D=1.25)$, Yoko $(D=1.26)$ and Mbakaou $(D=1.28)$. However, the non-parametric tests of Kruskal-Walis have shown that there is no significant difference in the distribution of species in this region. There is no significant difference in the distribution of these insects between the milieus. The species of tsetse flies identified were the species with zoophilic food nature (feeding with animals) and even ubiquitous (opportunistic) (Kohagne and Co., 2011). On the other hand the presence of G. palpalis spp and of G. fuscipes fuscipes, which are also the main vectors of the sleeping sickness could suggest the existence of a sanitary risk in this zone. Moreover, the ubiquity of $G$. palpalis spp, in all the prospected biotopes, testified of its capacity of resilience and of its affinity for the relative humidity and the temperatures between 20 and $25^{\circ} \mathrm{C}$, favored by the presence of rivers which together with the vegetation constitute the favorable environmental factors to survive (Schwetz, 1915; Kohagne and Co., 2011). On other hand, the source of food is also one of the factors that could explain the distribution of G. palpalis spp which food eclecticism favors the adaptation at different ecologic milieus (Laveissière and Co., 2000). The abundance of G. fuscipes fuscipes in this region concords with the old distribution map of tsetse flies in Cameroon which has shown a large distribution of this species in the part of the country infested by these insects (Rageau and Adam, 1953). This results confirm those obtained by Mbida and Co., (2009) and Doumba and Co. (2015) who shew that the zones dominated by forest constitute the main favorable biotopes to the development of tsetse flies, in particular G. fuscipes fuscipes which find the possibilities of rest and reproduction. The presence $G$. fusca congolensis could explain their ubiquity and affinity for forest zones and riverside (Dibakou and Co., 2015). These results confirm those obtained by Mounioko and Co. (2015) who showed a large abundance of tsetse flies in the Moukalaba Doudou national.

\section{Conclusion}

The knowledge based on the insects vectors of the pathogenic agents, in particular the tsetse flies, constitute and important element in anti-vectorial fight and against all the diseases transmitted by vectors. Thus, this work falls under the study of insects vectors of pathogenic agents in the parks. In the other hand, the problematic of biting flies is up to date in the frame of the impact of global changes on human society, in particular emerging diseases. This first study concerning the distribution of tsetse flies around the Mbam and Djerem Park has permitted to put in evidence 4 species distributed in two groups (Palpalis and Fusca) which live in harmony in the different prospected biotopes. The park is the biggest and the most diversified because of its ecotone. Knowing that the transmission risk of the sleeping sickness is all the greater than the presence of human being in the area of tsetse distribution is enduring (Laveissière and Co., 1985), one could suppose that the risks of THA transmission near this park are effective.

\section{References}

[1] Amsler S. et Filledier J. (1994). Attractivité pour les Tabanidae de l'association méta- crésol/octénol. Résultats obtenus au Burkina Faso. Revue d'Élevage et Médecine Vétérinaire des Pays Tropicaux 47, 93-96. 
[2] Annuaire statistique du Cameroun (2013). Recueil des séries d'informations statistiques sur les activités économiques, sociales, politiques et culturelles du pays jusqu'en 2013. INS, $536 \mathrm{p}$.

[3] Asonganyi T., Suh S., Tetuh M. D. (1990). Prevalence of domestic animal trypanosomiasis in Fontem sleeping sickness focus, Cameroon. Revue ElevageetMédecineVétérinaire des pays Tropicaux, 43 (1): 69-74.

[4] Bitome E. P. Y., Dechaume-Moncharmont F. X., Mavoungou J. F.; Mba O. R., Duvallet G. etBretagnolle F. (2015). Distribution and abundance of hematophagous flies (Glossinidae, Stomoxys, and Tabanidae) in two national parks of Gabon. Parasite 22, p. 25.

[5] Brunhes J., Cuisance D., Geoffroy B. et Hervy J. P. (1998). Les glossines ou mouches tsé-tsé Editions ORSTOM, Montpellier, France. CD.

[6] Challier A. et Laveissiere C. (1973). Un nouveau piège pour la capture des glossines (Glossina: Diptera, Muscidae): description et essais sur le terrain. Cah. ORSTOM, Ser. Entomol. Med. Parasitol. 11 (4):251-262.

[7] Chartier C., Itard J., Morel P. C. et Troncy P-M, 2000. Précis de parasitologie vétérinaire tropicale, Paris: Editions TEC \& DOC, $774 \mathrm{p}$.

[8] Desquesnes M., Dia L. M., Acapovi Yao G. L., Yoni W., Foil L. et Pin R. (2005). Les vecteurs mécaniques des trypanosomoses animales: Généralités, morphologie, biologie, impacts et contrôle. Identification des espèces les plus abondantes en Afrique de l'Ouest. Bobo-Dioulasso, Burkina Faso, Editions Cirdes, 68 p.

[9] Dibakou E. S., Mounioko F., Zinga-Koumba C. R., Mbang N. O. A., Acapovi-Yao G. L. et Mavoungou J. F. (2015). Distribution des Glossines vecteurs de la Trypanosomose humaine africaine dans le Parc National de Moukalaba Doudou (Sud-ouest Gabon), Journal of Applied Biosciences $86,7957-7965$.

[10] Djiteye A. (1992). Aperçu sur l'efficacité comparative de différents pièges et odeurs contre les mouches piqueuses (Diptera: Tabanidae et Muscidae) d'importance vétérinaire. In Premier séminaire International sur les Trypanosomoses Animales non Transmises par les Glossines, Annecy (France), 14-16 octobre.

[11] Djiteye A. (1994). Efficacité comparée des différents types de pièges et / ou associations d'odeurs sur les tabanidés, stomoxes et glossines présentes en zone soudano-guinéenne (Mali) G. m. submorsitans, G. tachinoides, G. p. gambiensis. Résumé Rapport d'étape, LCV de Bamako, Mali.

[12] Doumba N. A. G., Zinga K. C. R., Mounioko F., Mbang N. O. A., Mboye B., Maroundou A. P., Acapovi-Yao G. L., M'batchi B., Mavoungou J. F. (2015). Composition et diversité spécifique des glossines, vecteurs biologiques de la trypanosomose humaine africaine, dans la région de Ndendé (sud du Gabon).

[13] FAO (2002). Food, agriculture and food security: the global dimension. WFSO 2/Tech/Advance unedited version. FAO, Rome, 19-28.

[14] FAO (2014). Food and Agriculture Organization of the United Nations, FAOSTAT, data, Live animals, consulté le 27-12-16. http://www.fao.org/faostat/en/\#data/QA.
[15] Farikou O, Njiokou F, Simo G, Asonganyi T, Cuny G et Geiger A. (2010). Tsetse fly blood meal modification and trypanosome identification in two sleeping sickness foci in the forest of southern Cameroon. Acta Trop., 116: 81-88.

[16] Frezil J. L. et Carnevale P. (1976). Utilisation de la carboglace pour la capture de Glossinafuscipesquanzensis Pires, 1948, avec le piège ChallierLaveissière. Conséquences épidémiologiques. Cahiers ORSTOM, Séries Entomologie Médicale et Parasitologique, 14: 225-233.

[17] Gilles J. (2005). Dynamique et génétique des populations d'insectes vecteurs. Les stomoxes, Stomoxys calcitrans et Stomoxys nigerniger dans les élevages bovins réunionnais". Thèse de doctorat, Université de La Réunion, St-Denis, 140 p.

[18] Gilles J., David J. F., Duvallet G., De La Rocque S. et Tillard E. (2007). Efficiency of traps for Stomoxyscalcitrans and Stomoxysniger on Reunion Island. Medical and VeterinaryEntomology21, 65-69.

[19] Gouteux J.-P. etDagnogo M. (1986). Ecologie des glossines en secteur pré-forestier de Côte- d'Ivoire. 11. Comparaison des captures au piège biconique et au filet. Agressivité pour l'homme. Cah. ORSTOM sér. Ent. méd. Parasit. 24:99-110.

[20] Jaenson G. T., Dos Santos R. C. et Hall D. R. (1991). Attraction of Glossinalongipalpalis (Diptera: Glossinidae) in Guinea-Bissau to odorbaitedbiconical traps. Journal of MedicalEntomology28, p. 284-286.

[21] Kohagne T. L., Gounoue K. R., Mengue M. P., Kaba D., Louis F. J., et Mimpfoundi R. (2011). Enquête entomologique dans le foyer historique de trypanosomose Humaine Africaine de Bendjé (Gabon). Parasite 18, p. 1-7.

[22] Krčmar S. (2007). Reponse of horse flies (Diptera, Tabanidae) to canopy traps baited with 4-methylphenol, 3-isopropylphenol, and naphthalene. Journal of Vector Ecology 32, p. 188-192.

[23] Krčmar S., Mikuska A. et Merdic E. (2006). Response of Tabanidae (Diptera) to different naturel attractants. Journal of Vector Ecology 31, p. 262-265.

[24] Laveissière C., Couret D., Staak C. etHervouët J. P. (1985). Glossinapalpalis et ses hôtes en secteur forestier de Côte d'Ivoire. Relation avec l'épidémiologie de la trypanosomiase humaine. Cahier ORSTOM, série entomologie médicale et parasitologie, 23 (4): 297-303.

[25] Laveissière C., Grébaut P., Herder S. et Penchenier L. (2000). Les glossines vectrices de la Trypanosomiase humaine africaine. IRD and OCEAC, Yaoundé, Cameroun. 246 p.

[26] Legendre P. et Legendre L. (1998). Numerical ecology, 2nd English edition. Elsevier Science BV, Amsterdam. 853 pp.

[27] Maillot L. (1953). Carte de la distribution probable des sousespèces et variétés de Glossinapalpalis. Échelle 1/28 000000. ORSTOM, service cartographie, Paris.

[28] Maisels F., 2004. Cameroun: Mbam et Djérem, CANOPEE, 4p.

[29] Mavoungou J. F. (2007). Ecologie et rôle vecteur des stomoxes (Diptera: Muscidae) au Gabon. Thèse de doctorat. Université Montpellier III PAUL VALERY, p 137.

[30] Mavoungou J. F., Makanga B., Acapovi-Yao G. L., Desquesnes M. et M'batchi B. (2012). Chorologie des Tabanidae (Diptera) dans la réserve de Biosphère Ipassa-Makokou (GABON) en saison des pluies. Parasite 19, 165-171. 
[31] Mbang N. O. A., Mavoungou J. F., Mawili-Mboumba D. P., Zinga-Koumba R. C., Bouyou-Akotet M. K. et M'batchi B. (2015). Inventory of potential vectors of trypanosoma and infection rate of the Tsetse fly in the National Park of Ivindo, Gabon. African Health Sciences 15 (3), 762-767.

[32] Mbida-Mbida J. A., Mimpfoundi R., Njiokou F., Manga L. et Laveissière C. (2009). Distribution et écologie des vecteurs de la trypanosomose humaine africaine de type savanicole en zone de forêt dégradée au sud Cameroun: cas du foyer de Doumé. Bulletin de la Société Pathologique Exotique, 102: 101-105.

[33] Mihok S. (2002). The development of a multipurpose traps (the Nzi) for tsetse and other biting flies. Bulletin of Entomological Research 92, 385403.

[34] Mihok S. etMulye H. (2010). Responses of tabanids to Nzi traps baited with octenol, cow urine and phenols in Canada. Medical and Veterinary Entomology 24, 266-272.

[35] Mihok S. et Lange K. (2012). Synergism between ammonia and phenols for Hybomitratabanids in northern and temperate Canada. Medical and Veterinary Entomology 26, 282-290.

[36] Mihok S., Kangethe E. K., Kamau G. K. (1995). Trials of Traps and Attractants for Stomoxys spp. (Diptera, Muscidae). Journal of Medical Entomology 32 (3), 283-289.

[37] MINFOF (2007). Parc National du Mbam et Djerem, Plan d'Aménagement 2007-2011. Ministère des Forêts et de la Faune. 137p.

[38] Morlais I. (1998). Identification des trypanosomes chez les glossines en zones endémiques de trypanosomose humaine au Cameroun. Thèse, $229 \mathrm{p}$.

[39] Mounioko F., Dibakou F., Zinga-Koumba C. R., MbangNguema O. A., Acapovi-Yao G. L., Mutambwe S. et Mavoungou J. F. (2015). Rythme d'activité journalière de Glossinafuscipesfuscipes, vecteur majeur de la trypanosomiase humaine africaine dans le parc national de MoukalabaDoudou (Sud-Ouest Gabon). International Journal of Biological and Chemical Sciences 9 (1), 419-429.

[40] Njiokou F., Laveissière C., Simo G., Nkinin, S., Grébaut P., Cuny G. et Herder S., 2006. Wild fauna as a probable animal reservoir for Trypanosoma bruceigambiense in Cameroon. Infection, Genetics and Evolution, 6, 147-153.

[41] Njitchouang GR, Njiokou F, Djeunga HCN, Fewou P. M., Asonganyi T., Cuny G. et Simo G. (2010): Analysis of the domestic animal reservoir at a micro-geographical scale, the Fontem sleeping sickness focus (south-west Cameroon). J Cell Ani Biol, 4:73-80.

[42] Rageau J. et Adam J-P (1953). Répartition des glossines au Cameroun français, REMVPT, ORSTOM, 6p. Schwetz J. (1915). Preliminary note on the general distribution of Glossina palpalis in Lomani district, Belgian, Congo. Annals of Tropical Medicine and Parasitology, 9: 513-526.

[43] Simo G, Asonganyi T, Nkinin SW, Njiokou F, Herder S (2006): High prevalence of Trypanosoma brucei gambiens egroup 1 in pigs from the Fontemsleeping sickness focus in Cameroon. Vet Parasitol, 139:57-66.

[44] Simo G, Njitchouang GR, Njiokou F, Cuny G, Asonganyi T (2012): Genetic characterization of Trypanosoma brucei circulating in domestic animals of the Fontem sleeping sickness of Cameroon. Microb. Infect, 14:651-658.

[45] Van Hennekeler K., Jones R. E., Skerratt L. F., Fitzpatrick L. A., Reid S. A. et Bellis G. A. (2008). A comparison of trapping methods for Tabanidae (Diptera) in North Queensland, Australia. Medical and Veterinary Entomology 22, 26-31.

[46] Zinga-Koumba C. R., Acapovi-Yao G. L., Mavoungou J. F., Kohagne Tongue L., Mbang-Nguema O. A., Obame O. P. K. et Shango M. (2013). Influence de la saison sur l'écodistribution des glossines, tabanides, stomoxes du Baï de Momba Makokou, Gabon. Agronomie Africaine 25, 149-158.

[47] Zinga-Koumba C. R., Mbang-Nguema O. A., Kohagne T. L., Acapovi-Yao G. L., Obame O. K. P, Mutambwe S. et Mavoungou J. F. (2014). Contribution à l'évaluation de la diversité des vecteurs biologiques de la Trypanosomose Humaine Africaine et de leur activité journalière dans le Parc National de l'Ivindo (Nord-est Gabon). Journal of Applied Biosciences 80, p. 7060-7070. 